\title{
Another Look at the Origin of Late Blight of Potatoes, Tomatoes, and Pear Melon in the Andes of South America
}

\author{
Z. Gloria Abad and Jorge A. Abad, Department of Plant Pathology, North Carolina State University, Raleigh \\ 27695-7616
}

Late blight of potatoes (Solanum tuberosum L.), caused by Phytophthora infestans (Mont.) De Bary, is one of the most devastating plant diseases in human history. During the 1840s, the fungus caused epidemics in the United States and Europe culminating in the famous Irish potato famine of 1845 . These late blight epidemics brought hunger to many people and the migration and death of many others. Indirectly, late blight also was a stimulus to the origins of plant pathology as a science. Plant pathology began with the contributions of Berkeley and De Bary. Reverend Berkeley became the main supporter of the "fungal theory" of late blight (1845) (12), and Anton De Bary provided evidence that late blight was caused by the fungus that he named Phytophthora infestans (1876) (22). These pioneers also believed that the fungus was imported to Europe from the Andes of South America, the native land of potatoes $(12,21,22)$. Many other notable plant pathologists supported this idea until 1939, when Reddick presented the new concept that central Mexico was the center of origin of late blight (59). Today, Mexico is widely considered to be the center of origin of $P$. infestans $(26,27,31,47,74)$. According to current plant pathology literature, $P$. infestans was introduced from central Mexico to the United States in 1842, and thence to Europe in 1845 (26,27,31). In South America, the presence of late blight in Argentina in 1887 and Brazil in 1898 has been attributed to an introduction of potatoes from Europe in the 1880s (47). In current scientific literature, the first appearance of late blight in Peru was in 1929 (47) or 1947 (61), in Bolivia in 1943, and in Chile in 1949 (47); no dates have been established for other Andean countries such as Colombia or Ecuador $(47,61)$. The origins of the disease in South American countries other than Ar-

Corresponding author: Z. Gloria Abad

E-mail: gloria_abad@ncsu.edu

Accepted for publication 20 March 1997.

Publication no. D-1997-0428-05S

(C) 1997 The American Phytopathological Society gentina and Brazil have not been definitively explained.

It is widely accepted that Peru is the center of origin of potato, tomato (Lycopersicon esculentum Mill.), and pear melon (Solanum muricatum Ait.) $(36,48)$, the three major hosts of $P$. infestans $(1,3,19,67)$. Contrary to the concept that late blight is of recent occurrence in Peru and other Andean countries, strong evidence exists in the historical literature that the disease has been endemic in the area for centuries. This report examines the historical literature on the origin of $P$. infestans in hopes of shedding more light on this fascinating mystery. A preliminary report on this assessment has been published (2).

\section{Mexico as Center of Origin}

In 1928, Reddick (57) questioned the Andean theory of Morren, Berkeley, and De Bary and introduced his conclusion that central Mexico was the center of origin of late blight (59). In 1932, he had reported that, "the wild potato Solanum antipoviczii Buk. was found infected with late blight in a roadside at $59 \mathrm{~km}$. from Mexico city" (58). The natural infection of a wild potato in central Mexico was, according to Reddick, convincing evidence for the presence of the fungus in the area since remote times (59). Subsequently, other lines of evidence supporting Reddick's theory of Mexico as the center of origin of late blight have been developed $(26,27,31,47,74)$. As noted above, scientists consider that $P$. infestans was introduced from central Mexico to the United States in 1842 (in infected tubers of wild potatoes), and then to Europe in 1845 (26,27,31). However, several questions on this thesis need to be considered. For example, no natural infection on tubers of wild species from central Mexico was found by Reddick in 1932 (58) or by Rivera-Peña in 1988 (60). The later author, after an extensive study of wild potatoes in natural habitats in central Mexico, concluded, "The observations confirm that tubers are an unlikely source of infection... No tubers with $P$. infestans were found... Very few plants within a colony were attacked by late blight" (60). It is unlikely that in the 1840 s, the fungus could have been transported from Mexico to the United States or Europe in foliage or stems of a wild potato due to rapid deterioration of these organs.

The assumption that the disease first occurred in Europe in 1845, immediately after the arrival of the pathogen $(26,27,31)$, is also problematic. There is strong evidence that the disease was noticed almost simultaneously in 1842 in both the United States and Europe $(34,35,37)$. In the United States, it possibly was detected in 1842 in the vicinity of the ports of Philadelphia and New York $(37,53)$.

Furthermore, consideration needs to be given to the fact that in Europe the disease was reported at the beginning of the 1840s. In 1841, the potato disease (late blight) was detected in a few localities in Norway (Westrem, cited by 34 and 37) and in Belgium (43). In 1842, it was observed in at least six countries, including Belgium, Denmark, England, Germany, Holland, Ireland, and Scotland, according to a number of reputable reports $(25,37)$, including those of Berkeley (12), Jensen (34), Johnston and Fleming (35), and Morren (43). In 1845, Johnston and Fleming (35) conducted extensive surveys (containing 26 questions on the occurrence of the potato disease) among the farmers of Scotland, England, Ireland, Holland, and the United States. On the question: "Is the potato disease more extensive during the present than during the past years?" they concluded, "It has been observed to a greater or less extent for the last three seasons in various parts in Scotland at the same period of the year... The accounts we have obtained from other countries confirm this view. It has been observed for several years both on the Continent [Europe] and in America."

According to Jones et al. (37), the occurrence of the disease at about the same time in the United States and Europe indicates that the fungus was introduced from a single source in a short period of time. Furthermore, there is little or no evidence that the potato was grown in Mexico prior to the Spanish conquest (68); in fact, potatoes were not grown widely in this country until 1949 (47). The first definitive record of late blight disease on cultivated potatoes in Mexico was probably in a publication by Gandara in 1908 (28); the introduction of 
the fungus into Europe and the United States in the 1840s in cultivated potatoes from Mexico is highly improbable if not impossible.

\section{Historical South American Records}

In addition to the observations noted above, it is the evidence documented in the historical literature from South America that offers compelling reasons to question the Mexican theory of origin of the disease.

The perception of European scientists. The late blight epidemics of the 1840s naturally were the starting place for scientific speculation on the origin of the disease. Many prominent botanists, horticulturists, pharmacists, and others who contributed to an understanding of the potato disease (late blight) between 1845 and 1846 had the perception that the causal agent was imported from the Andes (the native land of potatoes) of South America to Europe (Morren [43,44], Marchal [40], Boussingault [16], Berkeley [12], Bonjean [13], Münter [45], and Payen [52]). In the following years, many other eminent plant pathologists from Europe and the United States reached a similar conclusion, including De Bary (21,22), Farlow (25), Jensen (34), Roze (62), Prunet (55), Jones et al. (37), Vowinckle (73), and Large (39). Among the most important supporters of the Andean connection were Morren, Berkeley, and De Bary, the principal proponents of the fungal theory of disease $(12,21,22,43)$.

Professor Morren from Belgium suggested that the potato disease was caused by a fungus that he named Botrytis (43). He described (in French) (Fig. 1) the occurrence of the potato disease in Belgium that was first observed in 1841 as follows: "A terrible curse struck the plantation of the potatoes in Belgium. It was on July 24 that it appeared as first time with some intensity between Xhendremal and Landen, but in 1842, the same disease was observed in Liege province. I presented a public lecture of Agriculture at University of Liege on March 24, 1843 in the presence of a great number of farmers. I presented the history, the means to control and prevent the future of this disease that is affecting this country today to be overcome." In the same publication, Morren remarked, "It is infinitely probable that the Botrytis is indigenous in America and was introduced to Europe in tubers."

Berkeley, in his publication of the Potato Murrain (Late Blight) in 1846 (12), stated, "It is probable that it [the disease] has existed [in Europe] for some time without attracting much attention; at any rate it is not the birth of one year only... Dr. Morren informs us in his admirable little pamphlet that it has been known for two or three years in Belgium... In a recent communication to the French Academy, Nov.
17, 1845, M. Boussingault states, on the information of M. Joachim Acosta, that the malady is well known in rainy years at Bogota, where the Indians live almost entirely on potatoes... This singularly confirms Dr. Morren's notion that the disease, like some other afflictions of the vegetable Kingdom, is of American Origin.'

De Bary in 1861 (21) wrote (original in German), "It is very probable that the disease exists in the Andes since a long, long time, because in South America the potato tubers are diseased very often, in a way that can be considered identical with the disease... In the year 1571, the Jesuit Joseph Acosta (Münter, 1846) observed in the Andes of Peru that after bad and cold weather the potato tubers were often rotted in the ground caused by 'gangrene' or 'mildew' [bran or mehlthau] [añublo]. Payen describes a disease, predominant in the Cordilleres, which he knew from the descriptions of Mr. Gjoudot, and which was very similar to 'rotten tubers' from the Cordilleres [imported to Europe]. On the 17 of November 1845 Boussingault presented a letter from Acosta, to the French Academy...." (Also mentioned by Berkeley.)

Payen (cited by De Bary) stated in his original publication (in French) (52), "This second form of the special alteration [of tubers] is very much like the one that reigns in the Andean Cordilleres according to Gjoudot, whom we met in 1845 . He also attributes it to a particular species of reddish mushroom." Payen was the first to report the disease on tomatoes in Europe in 1846 (52).

The importation of potato varieties from Peru at the beginning of the 1840 s was documented by many scientists of the epoch, including Martens, Bourson, Dumortier, Decaisne, and Milne $(15,23,41,63)$. Unfortunately, some potato varieties imported from South America into Europe at that time may have initiated the disease in Belgium and the Netherlands in 1841 to 1842 (14,15,23,41,63). Decaisne (23) stated (in French) that in 1843, "In Belgium, all the varieties have been affected...two varieties, 'cordillieres' and 'lima' have absolutely not produced in a well cared land in a common year... The varieties 'peruviennes', 'cordillieres'... as well as several other varieties recently introduced have completely been devastated and have not even produced any tuber in the Netherlands." Martens in 1845 in Belgium commented (original in French), "There is no doubt that any potato variety has been not attacked by the plague, no even 'cordillieres', recently introduced" (41).

The endemic nature of late blight in potatoes and other solanaceous crops in the Andes of South America also was postulated by other researchers $(25,55)$. In 1875 , Farlow, a prominent professor, who was among the first to teach about plant diseases as a special subject in the United States, stated, "The more probable supposition would be that the disease, as well as the potato, was imported from Peru. In that

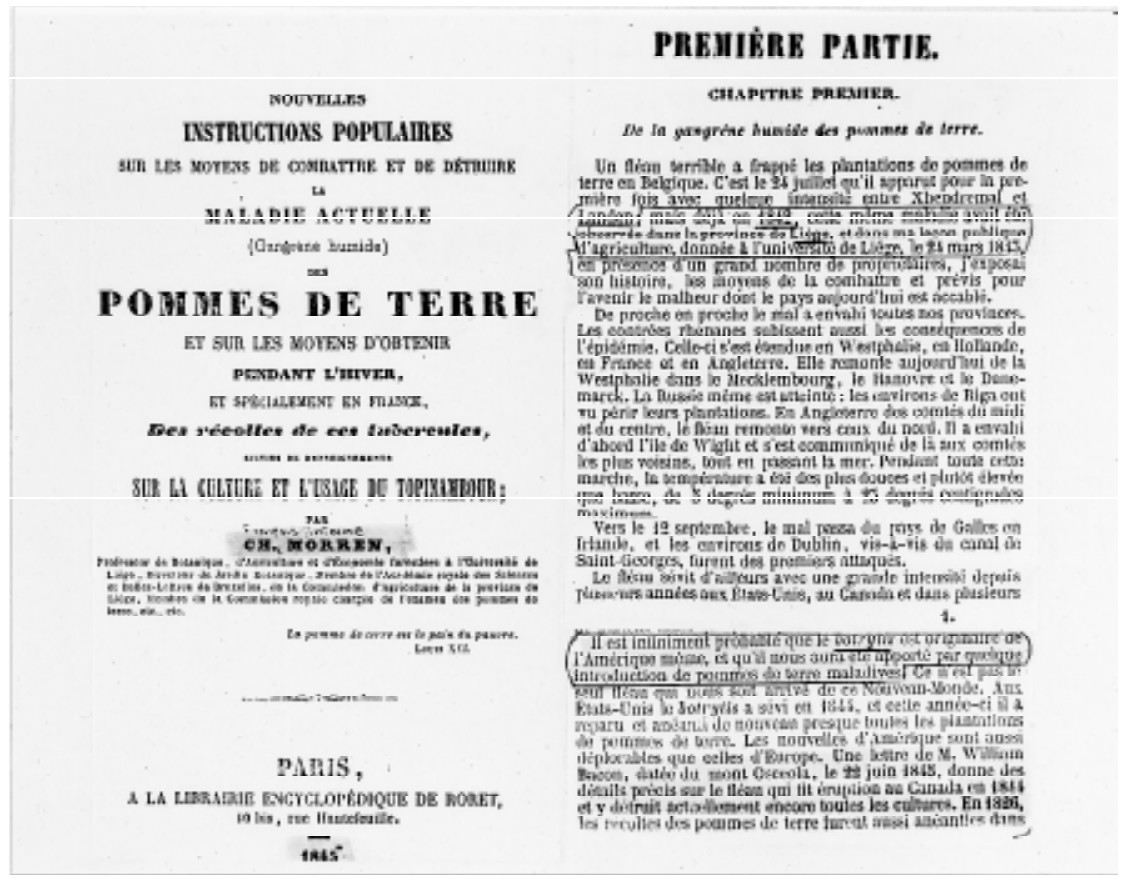

Fig. 1. Professor Morren's publication of late blight in 1845 (43). Shown are pages describing the presence of the disease in Xhendremal, Landen (1841), and Liege (1842), Belgium, and the suggestion on the origin and introduction of the Botrytis from South America. 
country, the Peronospora lives upon different species of Solanum, of which there are a good many that inhabit Peru" (25). Prunet (1902) also concluded, "The mildew of the potato exists in an endemic state in the Andes region the origin of its host plant; there it is found not only on potatoes but moreover in other Solanaceous" (55).

It is well established that Peru is the center of origin of the potato, tomato, and pear melon $(36,48)$. The host range of $P$. infestans in Peru includes cultivated forms and wild relatives of potato, tomato, and pear melon, other solanaceous plants, and members of other plant families such as Nolana humifusa (Gouan) Johnson and $N$. gayana (Gaud.) Koch $(1,3,19,67)$.

The explorers from South America. In 1928 and 1939, when Reddick suggested that late blight was not of South American origin, he based his argument on the writings of two Spanish travelers, Father Acosta in Peru (1590) and Colonel Acosta in Colombia (1845) $(57,59)$. However, it is strange that Reddick did not refer to the publications of Morren (43), Berkeley (12), and De Bary (21). Reddick referred to Father Acosta's publication of 1590 by citing from Münter (45) and Vowinckle (73). He wrote, "Münter as well as Vowinckle, cite a passage from Acosta which is interpreted to mean that he had observed potato rot in South America. The word used by Acosta is 'añublan'. If a contemporaneous Spanish dictionary is consulted, the word 'añublan' refers to the production of injury by the burning of tissue by the sun's rays when passing through droplets of water. ...he meant nothing more than the potatoes sometimes spoiled in the ground because they became frozen." Münter's citation of Acosta in 1846 (45) (also cited by De Bary in 1861 [21]) referred that, "Joseph Acosta, a Jesuit, visited Peru in the year $1571 \ldots$ Of special interest is this notice, that these papas [potatoes] are often killed by frost and thus spoil in the ground itself due to añublan, that is blight or mildew, which is attributed by Acosta to the bad weather." Father Acosta's publication referring to añublo in potatoes of Peru is mentioned also in other papers on late blight $(37,73)$.

It appears that Reddick (57) may not have examined the original book published by Father Acosta in 1590 and older Spanish dictionaries (prior to 1928), because his information describing damage only in tubers is questionable. In Father Acosta's book (20), the statement on the disease in old Spanish (translated into modern Spanish) states, “...en otras partes de Indias, como es lo alto de la Sierra del Pirú y las provincias que llaman del Collao..., en cuyo lugar usan los indios otro género de raíces que llaman papas... En fin, estas raíces son todo el pan de aquella tierra, y cuando el año es bueno de estas, están contentos, porque hartos años se les añublan y hielan en la misma tierra; tanto es el frío y destemple de aquella región." The English translation of the passage is as follows, "...in other parts of the Indias,... as it is in the highlands of Piru and

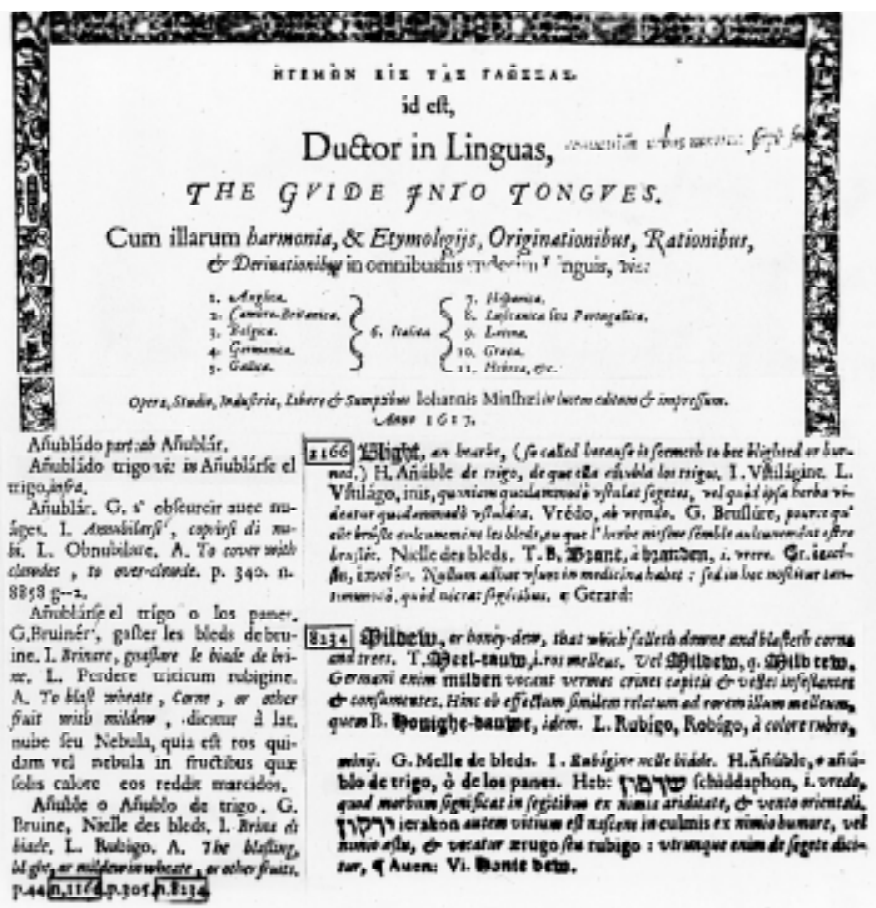

Fig. 2. Minshew's Etymological Dictionary (42) published in 1617. Spanish words show etymology in eleven languages. Notice the meaning of Añublado and Añublar in different languages, and observe in the last paragraph the English equivalence of Añublar as "the blafting, blight, or mildew in wheat, or other fruits." Also, notice codes 1166 and 8234. These numbers correspond to blight and mildew, respectively. They provide the word Añublo as one of their etymological words. from the Collao provinces [currently Peru and Bolivia] the Indians use other kind of roots that they call papa [potato]... These roots are the bread of all that land, and when the year is good, they are happy, because in many years, potatoes 'añublan' [blight] and 'hielan' in the same soil due to the cold and high humidity of that region."

In the dictionary Ductor in Linguas and Vocabularium Hispanicolatinum, published by Minsheu in 1617 (42), the definitions for Spanish words are listed for 11 languages, including Dutch, English, French, Greek, Hebrew, Italian, Latin, Portuguez, and so on (Fig. 2). In Minsheu's dictionary, añublo is translated as "the blafting, blight or mildew in wheat, or other fruits," and some etymologies of añublo in other languages include "annubilarfi, blaft, brina, bruinér, bruine, brinare, obnubilary, rubigine, rubigo," and so on (Fig. 2). Etymologies of English words blight and mildew refer to añublo in the same dictionary (42). Blight and mildew are common names for the disease in English speaking countries (33). Añublo means gangrene, or brun in French, and these were terms used by Morren in 1845 (43). Münter used the terms brand or mehltau in German in 1846 (45), as did De Bary in 1861 (21). In three Spanish dictionaries published in 1721, 1803, and $1826(7,56,64)$, añublo was similarly defined as tizón or blight. In a Spanish dictionary published in 1984 (71), añublo is still in use and defined as "the disease of the potato caused by Phytophthora infestans." In fact, añublo and tizón tardio were names used to describe late blight early in this century in Mexico (28). Tizón tardio is the present most common name of the disease in many Central and South American countries $(1,11)$. Destemple means humidity (64), which is the most important environmental condition for the occurrence of the disease.

According to Reddick's interpretation (57), Acosta mentioned only damage to potato tubers. Father Acosta, however, apparently observed two symptoms of the disease affecting potatoes in rainy areas of the Andes of Peru and Bolivia in 1590 (20). When he mentioned añublan, he possibly was referring to damage in the aerial part of the plant (añublo = blight); when he mentioned hielan in the same soil, he probably alluded to disease symptoms in tubers. (Hielo and rancha are names assigned to late blight in Peru.) If one accepts the validity of the terminology (i.e., añublo = late blight), perhaps Father Acosta in 1590 made one of the first reports of late blight affecting potatoes in the Andes of Peru and Bolivia (20). But there is more to the story. The occurrence of the disease in the Andes prior to the epidemics of Europe and the United States in the 1840 s is suggested also by two other communications $(40,62)$.

Marchal in 1845 (40) reported the following to the Academy of Royal Society of 
Bruxelles (Fig. 3): "Don Vincent Pazos, former general consul of Bolivia in London, is now in Bruxelles... He recently communicated to me in Spanish some information about the causes of the potato disease, and asked me to report them to the Academy. ...the potato is cultivated on both slopes Oriental and Occidental chains of the Cordilleras.... The extraordinary rains provoke in the plants the growth of a substance parasite, that he thinks is a fungus, or animal or zoophyte. But, he maintains that identical symptoms of decay of potato have sometimes been observed in its native land... The excess of equatorial rains in Peru, enhances the same disease with which European potatoes have been affected during the present year...."

In 1845, D'Orbigny, a prominent explorer in South America (24), presented a communication, "Note sur la pomme de terre et sa maladie" (62) to the Societe Centrale d'Agriculture de France in which he states, "Potato is a crop that is the base of nourishment of the habitants of temperate regions in the Bolivian and Peruvian Andes... I have effectively learned from the inhabitants of Bolivia the name of the potato disease, its causes, prevention, and exterior symptoms... The Aymaras, indigenous people living in the vicinity of La $\mathrm{Paz}$, in Bolivia, have known since remote times of the disease that struck potatoes in Europe this year... This disease thrives particularly on the Oriental side of the Andes where rains are abundant... In the low valley always the humidity is present and potato is more susceptible to get disease, than at the superior boreal part where it is exempt... The excess of humidity is related to be the cause of the disease of potato that is thriving this year in Europe."

Like D'Orbigny and Pazos, scientists today such as Ugent in 1970 believe that in the Andes of Peru and Bolivia, potatoes had been cultivated for centuries primarily in the higher elevations in order to escape from late blight disease (69). Potato production in lower and intermediate valleys of the highlands and on the coast was initiated in the middle of the last century (69).

The possible occurrence of the disease in Colombia in the years 1762 and 1767 was suggested in the following communication read at a meeting on "The Potato Disease" (late blight) held by the American Agricultural Association in 1847 (9). "Mr. Williamson read the following abstract, translated from the Transactions of the Viceroy of Santa Fe of Bogota, at the time it was under the dominion of Spain: In 1762, the entire potato crop of all the provinces of the Viceroy, for that year and the year previous, rotted in the ground, or died while in a growing state. A commission was appointed to investigate the subject, and after visiting a large number of provinces, they were unable to ascertain from what cause the rot proceeded... From an old Indian..., they learned that a tradi- tion had been handed down by his tribe for more than a hundred years, that "when the potato did not grow good, they must plant the seeds collected from the healthy vines, and in a certain number of moons all would be right again'."

On 17 November 1845, Boussingault communicated to the French Academy of Sciences the following letter sent to him from Colonel Joachim Acosta in Colombia entitled "Sur la maladie des pommes de terre dans la Nouvelle-Grenade" (16), "The potato disease is found on the lands of Bogota, in rainy years, and the same every year in wet and marshy places. This is a species of fungus that has an excrescence which develops at different parts and which corrodes more or less deeply the tubers. However, that which remains after removing the spoiled part is still used as food, although this substance is far from being as good food as from healthy potatoes. You know better than I that potatoes are indigenous to the Andean plateaus, and I don't doubt the point that the disease of which I have spoken has always been known; but never alarmed the Indians, some of whose primary food is potatoes... At the moment of sending you this note, one gave me some potatoes spoiled by the disease which has spread lately in Europe, and I had been asked to be able to decide if it is the same as that in the native land. The exterior aspect of those that I examined differ from those of Bogota, these do not present any type of exterior excrescence, but the nature of the interior damage seems to me identical. Following this communication, which seems to establish that the disease which raged this year in Europe is endemic in the Cordilleras...Mr. Boussin- gault added that he understood well that [South] American farmers were little preoccupied by this disease, because potato culture is continuous, it is not necessary to save the tubers. Now in Europe, it is above all in the storage and silos that the disease progress most greatly....the loss which, at the moment of harvest, does not attain more than $8 \%$, increases after short time in tubers in silos, to about $33 \%$, because of the rapid contagion."

Boussingault's communication of Acosta's letter of 1845 was cited by a number of prominent scientists, including Morren (43,44), Berkeley (12), De Bary (21), Bonjean (13), Jensen (34), Jones et al. (37), Vowinckle (73), and Large (39). In spite of that, Reddick in 1928 (57) questioned the validity of Acosta's evidence, stating that "it is extremely difficult to see how a Colonel's testimony adds anything whatever to our knowledge of the disease." However, it should be noted that Colonel Acosta was not merely a soldier. In fact, he was the author of a number of books, including a Historical Compendium of New Granada, published in 1848 (8). It is important to consider also that this communication was presented during a period when many of the best observations and descriptions of plants and agriculture were made by gentleman observers or amateurs.

Early reports by South American scientists. The occurrence of late blight in South America suggested by explorers and other amateurs was later confirmed by reports of plant pathologists who began working in the region. Early reports in Peru included those of Garcia-Merino (29), Vanderghem (72), Herrera (32), Towsend and Abbott (66), Abbott $(5,6)$, and Garcia-

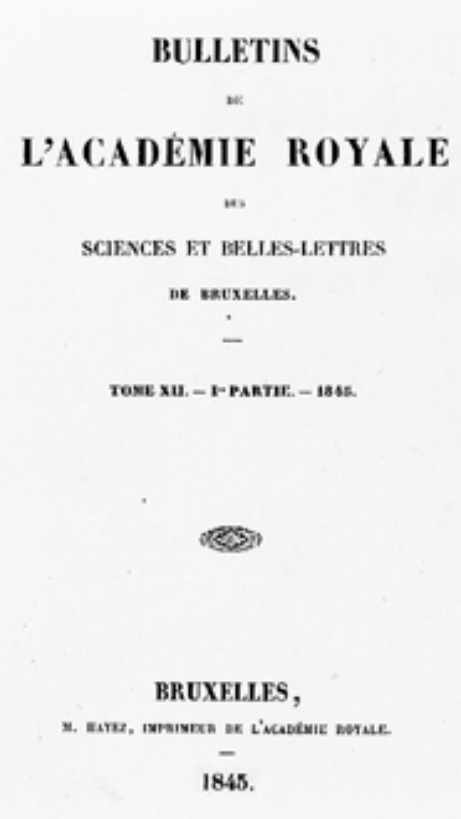

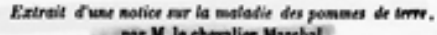
Lasdres, en ee ce momeot $\$$ Bruselies, poer tablir en

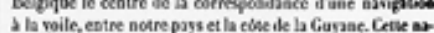
Il a voile, entre notre pays et la edoe de la Gagane. Certe as. vigation partinit à la vapear, Jepais Pan, dass la Gegas

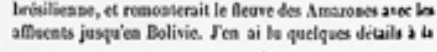

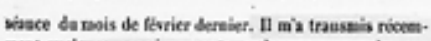
aeat quelques renseigaemeats, $e \mathrm{a}$ langue enpogsole, sur les causes de la maladie des pommes terre, en mode

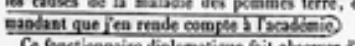
Ce hacthanaire diploenatipue lait observer sabord que and dass retut de coltere ef dans l'état sompe; que ciot ralineat priseipol de ses cormpatrintes, tast Espogaols

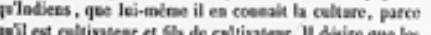
qwîl est ebltivatear et Slb de colltivatewr. Il daire que les renseigbersests quīl a'enrole soicat aecseillis mee iedulgeace, parce que les scieaces de la bestigue et de Therti. calture, soes le mpport de lear theorie, lai sost peu

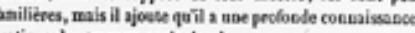
peatigne des tranax ayricoles de son pays.

La priscipale easese de la maladie de oe rigetal en Eitrope, qai fat ingont en tat de kequme et non a Tite

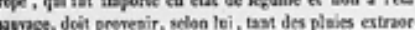

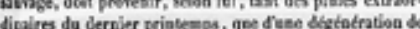
dimires du vernier printemps, qDe duec digtatration de

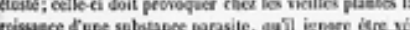

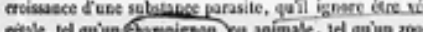

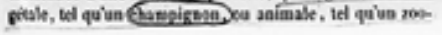

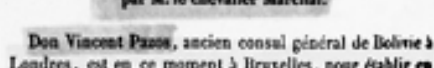
oete plante fariassese esiste as milieu de randinue du

Fig. 3. Bulletin of the Academy of Royal Society of Bruxelles published in 1845 (40) and part of Marchal's report to the Academy on the verbal communication of Vincent, Pazos consul of Bolivia in London, with regard to the occurrence of the disease in the Andes of Peru and Bolivia. 
Rada (30). Garcia-Merino, in the first book of plant pathology published in Peru (11), mentioned that in 1868 a great epidemic of "hielo" (blight) affected the crops of the potato, tomato, and pear melon in the coastal valleys of Lurin and Lima (29). He indicated that the hielo disease had been observed in previous years but without severe damage. The Spanish word hielo, literally translated into frost in English, could lead to misinterpretation of reports of late blight in the area. Garcia-Merino's report is important because it describes hielo as the name of the late blight in the coastal area where temperatures never decline below $10^{\circ} \mathrm{C}$; therefore frost never occurs. Today, hielo is used to describe late blight of potato, tomato, and pear melon in the coast, highlands, and high jungle $(1,10,11,46)$. Late blight on pear melon and its wild relative, Solanum caripense Kunh, was reported in Ecuador by Lagerheim in $1890(38,55)$. Presence of the disease on potato and pear melon in Ecuador also was confirmed by Pachano in 1918 and 1920 $(50,51)$. From Peru in 1907, Vanderghem published the treatise "Fitoftora infestans o enfermedad de la papa" (72) in which he stated, "It is admitted that the disease exists since immemorial times in the Andes" (Fig. 4). Abbott in 1928 remarked, "The 'hielo' or 'rancha' of potato is native of the highlands of Peru and Ecuador from where it has been introduced to Europe and other countries in the world through potato seed" (5). The occurrence of the disease in Colombia also was documented early in this century by Toro in 1927 (65), Chardon in 1928 (17), and Chardon and Toro in 1930 (18).
More recent reports. Bazán in 1965 (11), Ugent in 1970 (69), and Abad in 1983 (1) have suggested that the disease could have originated in the Andes. In Peru, Bazán (11) stated, "Probably the disease was introduced to Europe in the 1830's in importations from South America. It is difficult to trace with certainty the history of 'hielo' disease of potatoes in the world, but it is possible that this is originated in South America, the origin center of this plant. In the year 1876, a disease denominated 'hielos' that in previous years occurred sporadically, was intensified. It is possible that the disease has existed since remote times in the highlands of Peru." Ugent (69) remarked that "The homogeneous field populations of potato in Europe and in the US in the 1840's, like today, are extremely vulnerable to destruction by late blight. However, in the heterogeneous potato populations of the Andes, human and natural selection have acted for thousands of years to mitigate against disease."

\section{Why South American Historical Reports Are Not Widely Known}

Although the nineteenth century theory regarding the Andes of South America as the home of late blight had many supporters, the theory was abandoned because of a lack of historical and scientific evidence. Thus, the Mexican theory of origin postulated by Reddick in 1928 and 1939 (57,59) became dogma among plant pathologists. The reasons for the failure of scientists to cite the historical evidence for a South American origin of late blight are most likely due to the lack of access to historical

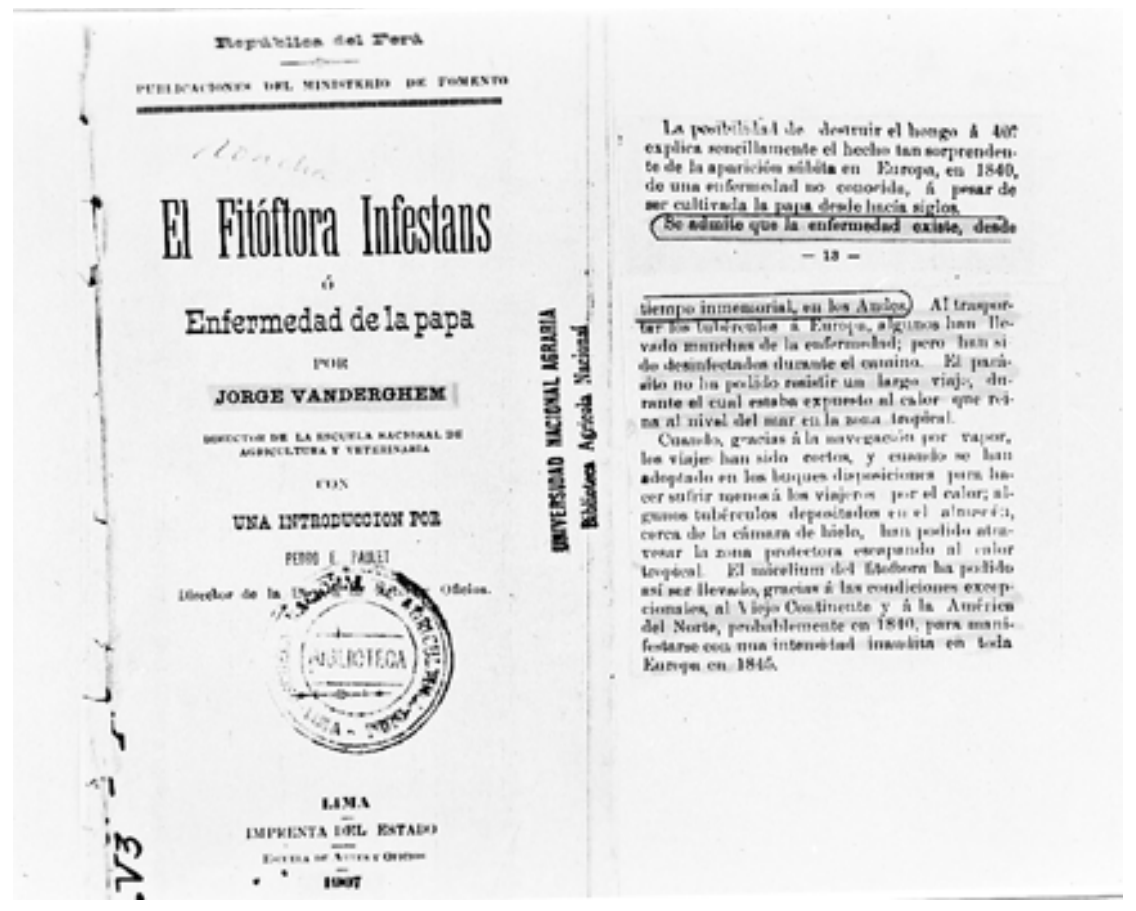

Fig. 4. A 1907 publication on late blight in Peru by J. Vanderghem (72) referring among other facts to the occurrence of the disease since remote times in the Andes and part of Jensen's theory (34) on the transportation of late blight from South America into Europe in the 1840s by means of the recently invented steamships.

reports and to the reports of Reddick $(57,59)$ and Abbott $(5,6)$. When Reddick in 1928 (57) questioned the Andean theory, he stated that " $P$. infestans is not thought to be endemic to South America, but to have been introduced there and into Europe on some other solanaceous hosts." In 1939 (59), he remarked that "The most outstanding bit of evidence that the fungus is not enphytotic [endemic] in South America is that of all the thousands of samples of potatoes taken from South America not one ever has been found which shows any resistance to the disease." Abbott reported in 1928 that hielo disease was of universal occurrence in all the potato areas in Peru (5). In 1931, he retracted his conclusion and insisted that hielo was observed not to be universal in Peru, occurring very infrequently in the highlands (6). According to Abbott, this fact supported Reddick's concept that the fungus was not native to South America (6). Reddick and Abbott, however, perhaps did not realize that late blight is endemic in Peru (especially in the Andes), that in certain zones the disease is of cyclic occurrence, and that in the 1930 s potatoes were mostly cropped in high elevations where the disease was not prevalent (69). Moreover, reports published in the 1950s (46) state that in certain areas of the Andes, under conditions highly favorable for late blight, little disease was observed, possibly due to the fact that the principal cultivars planted were native cultivars with durable resistance (mostly $S$. tuberosum subsp. andigenum). Now it is also known that in the Andes, a number of potato cultivars are grown with significant levels of resistance to the disease (4).

The fact that many historical reports on the disease in Andean countries contain unfamiliar words (to scientists working outside of South America) associated with late blight must have contributed to the scarcity of citations of these early reports. We have already explained the problems of omission of añublo and the possible misinterpretation of hielo (by frost). Some other Spanish words assigned to late blight in the area include Fitoftora, palo negro, seca-seca, tintorera, and so on, and native Indian words such as lancha, rancha, ranza, yanarancha, and so on $(1,10,11,20$, 29,46,72).

\section{Late Blight from the Andes to Europe and the United States}

Jones in 1912 (37) presented the following statements in regard to this topic, "the details of the introduction of late blight (native upon the wild potato of the Andean regions) in the 1840s from South America into Europe, and subsequent spread in this area, constitute one of the most interesting chapters of the history of plant pathology... The question naturally arises as to why the disease was not transported in the earlier shipments from South America?...Jensen in 1887 presented an 
interesting and plausible theory on the transportation...by means of the recently invented steamships...". The concepts of Jensen (34) were also accepted by Prunet in 1902 (55) and Vanderghem in 1907 (72). (Part of the last report in Spanish is in Figure 4.)

Bourke (15), Semal et al. (63), and Bourke and Lamb (14) are contemporary scientists who suggest that the disease could have been introduced from the Andes of South America to Europe in the 1840s. Bourke in 1964 (15) points to an introduction from the Andes considering that, "The timing and method of disease entrance are easier to demonstrate for the Andes [than for Mexico]. The newly independent South American states [1820 to 1830 s] opened up trade with Europe and North America and this was greatly expanded with the guano boom which commenced in 1840. .... among the newly introduced varieties which went down in the first attack in Belgium in 1845 were three which bore the significant names, 'Lima', 'Péruviennes' and 'Cordiliéres'." Semal et al. in 1983 supported the referred Bourke's concepts (63). More recently, Bourke and Lamb in 1993 (14) pointed out, "There is still no agreement where the cradle of the causal fungus was located, with the main body of opinion divided between Mexico and the Andean homeland of the potato... A ready means of transport of diseased potatoes from Peru to the USA and Europe in the early 1840's was provided by a large fleet of cargo boats which was engaged in catering for the guano boom of those years... It seems most probable that the blight came from America to Europe in a cargo of potatoes officially imported into Belgium in an effort to bring new vigor into an ailing crop."

\section{Conclusions, \\ Current and Future Studies}

The reported historical literature supports the concept that the late blight disease may have been endemic in the Andes of South America for centuries. The historical records also suggest that the first migration of the fungus to Europe and the United States in the 1840s was from the South American Andes. Some possible lines of scientific connection to the Andes as the cradle of $P$. infestans have been reported previously (4). Although it is clear that central Mexico is a center of diversity for the fungus, it is not yet clear whether the center of origin of $P$. infestans is located in the Andes of South America or in central Mexico. Many important historical and scientific questions still remain to be answered. The concept that a center of diversity is not the same as a center of origin should be examined. Studies of populations of $P$. infestans in Andean countries could shed important light on this and other questions. Little is known about isolates from native potatoes and the wild relatives, not only of potato, but also of tomato and pear melon. Perhaps interesting points in support of the Andean theory are the predominance of the A2 type in complex isolates obtained from both cultivated and native potatoes from Bolivian Andes (183 isolates all A2) (54) and the presence of the A2 type in wild Solanaceous spp. in Ecuador (49). Molecular studies of the fungus in museum and herbarium specimens from South America, Mexico, Europe, and the United States would provide valuable information on this matter.

Currently, we are analyzing for the presence of $P$. infestans in ancient potatoes (8000 to 2000 B.C.) from Peru using specific primers to amplify DNA from an internal transcribed spacer (ITS) region of ribosomal DNA by PCR (J. Abad, unpublished). The ancient potatoes were obtained by D. Ugent (Ethnobotanist of Southern Illinois University) in coastal Peru (70). Future research on the origin of $P$. infestans could improve the understanding of the evolution of this fungus, and perhaps will generate new ideas to facilitate the control of this destructive pathogen that caused one of the most devastating plant disease epidemics in human history and still is a threat to potato production.

\section{ACKNOWLEDGMENTS}

We thank Arthur Kelman, David Shew, Paul Peterson, Jean Ristaino, and C. Lee Campbell, Department of Plant Pathology, North Carolina State University, for their valuable comments on the manuscript. We also thank C. Lee Campbell and Katherin Hoffman, Department of Plant Pathology, for the German translation; Mary Barbercheck, Department of Entomology, and Vincent Robert, Department of Crop Science, for the French translation. The authors also thank A. Baker Ward and personnel of the Interlibrary Center at North Carolina State University and Cecilia Ferreyra and personnel of the Library at the International Potato Center, Lima, Peru, for helping with the retrieval of sources. This study was supported by the Department of Plant Pathology at North Carolina State University.

\section{LITERATURE CITED}

1. Abad, Z. G. 1983. Phytophthora infestans en la zona Central del Perú: Rango de hospedantes, variabilidad, y resistencia varietal. M.Sc. thesis. Universidad Nacional Agraria, Centro Internacional de la Papa, Lima-Perú.

2. Abad, Z. G., and Abad, J. A. 1995. Historical evidence on the occurrence of late blight of potato, tomato and pear melon in the Andes of South America. Pages 36-49 in: Phytophthora infestans 150. L. J. Dowley, E. Bannon, L. R. Cooke, T. Keane, and E. O'Sullivan, eds. Boole Press Ltd., Ireland.

3. Abad, Z. G., Abad, J. A., Fernadez-Northcote, E. N., and Ochoa, C. 1995. Host range of Phytophthora infestans in central Peru and list in the world since 1840's. Resistance on wild tomatoes. (Abstr.) Phytopathology $85: 1173$.

4. Abad, Z. G., Abad, J. A., and Ochoa, C. 1995. Historical and scientific evidence that supports the modern theory of the Peruvian Andes as centre of origin of Phytophthora infestans. Pages 239-245 in: Phytophthora infestans 150. L. J. Dowley, E. Bannon, L. R.
Cooke, T. Keane, and E. O'Sullivan, eds Boole Press Ltd., Ireland.

5. Abbott, E. V. 1928. La "roña" y el "hielo" o "rancha" de la papa. Vida Agric. (Lima-Perú) 5:1005-1010

6. Abbott, E. V. 1931. Further notes on plant diseases in Peru. Phytopathology 21:10611071 .

7. Academia Española, La. 1826. Diccionario de la Lengua Castellana. Paris. En la casa de Mason e hijo.

8. Acosta, J. 1848. Compendio histórico del descubrimiento y colonización de la Nueva Granada enel siglo décimo sexto. Impr. de Beau, Paris.

9. Allen, A. B., ed. 1847. The potato disease. Am. Agric. 6:44-45.

10. Bazán de Segura, C. 1952. El "hielo" o "rancha" de la papa en el Perú. Estación Exp. Agríc. Molina. Bol. No 45.

11. Bazán de Segura, C. 1965. Enfermedades de cultivos tropicales y subtropicales. José de Segura Montoya. Ed. Editorial Jurídica, LimaPerú.

12. Berkeley, M. J. 1846. Observations, botanical and physiological on the potato murrain. In: Phytopathological Classics, No 8. American Phytopathological Society, East Lansing, MI.

13. Bonjean, J. 1846. Monographie de la pomme de terre. Chambéry Imprimerie du Gouvernement, Paris.

14. Bourke, A., and Lamb, H. 1993. The spread of potato blight in Europe in 1845-6 and the accompanying wind and weather patterns. The Meteorological Service, Glasnevin Hill, Dublin. By permission of the Commission of the European Communities.

15. Bourke, P. M. A. 1964. Emergence of potato blight, 1843-1846. Nature 203:805-808.

16. Boussingault, M. 1845. Communique les extraits suivants d'une Lettre de M. le colonel Acosta "Sur la maladie des pommes de terre dans la Nouvelle-Grenade". C. R. Hebd. Séances Acad. Sci. Paris. XXI) 55:1114-1145.

17. Chardon, C. E. 1928. Contribución al estudio de la flora micológica de Colombia. Bol. Real Soc. Esp. Hist. Nat. 28:111-124.

18. Chardon, C. E., and Toro, R. A. 1930. Mycological explorations of Colombia. J. Dep. Agric. Porto Rico. 14:195-357.

19. De Abad, G., and Henfling, J. 1982. Hosts of Phytophthora infestans (Mont.) De Bary in the central region of Peru. (Abstr.) Fitopatología 17:3.

20. De Acosta, J. 1590. Historia Natural y Moral de las Indias en que se tratan las cosas notables del cielo, y elementos, metales, plantas y animales. Impr. en casa de Iván de León.

21. De Bary, A. 1861. Die gegenwärtig herrschende Kartoffelkrankheit, ihre Ursache und ihre Berhütung. U. Förftner'f dye Buchhandlung. Felix: Leipzig.

22. De Bary, A. 1876. Researches into the nature of the potato-fungus, Phytophthora infestans. J. R. Agric. Soc., England 12:239-269.

23. Decaisne, M. J. 1846. Histoire de la maladie des pommes de terre en 1845. Librarie Agricole de Dusacq. Ed. de la Maison rustique et du Bon Jardinier. Rue Jacob, No 26.

24. D’Orbigny, A. 1945. Viaje a la América Meridional. Vols. I-IV. Editorial Futuro. Buenos Aires, Argentina.

25. Farlow, W. G. 1875. The potato rot. Bull. Bussey Inst. 1:319-338

26. Fry, W. E., Goodwin, S. B., Dyer, A. T., Matuszak, J. M., Drenth, A., Tooley, P. W., Sujkowskii, L. S., Koh, Y. J., Cohen, B. A., Spielman, L. J., Deahl, K. L., Inglis, D. A., and Sandlan, K. P. 1993. Historical and recent migrations of Phytophthora infestans: Chronology, pathways, and implications. Plant Dis. 77:653-661.

27. Fry, W. E., Goodwin, S. B., Matuszak, J. M., 
Spielman, J., and Milgroom, M. G. 1992. Population genetics and intercontinental migrations of Phytophthora infestans. Annu. Rev. Phytopathol. 30:107-129.

28. Gandara, G. 1908. El Añublo o Tizón Tardio de la Papa. Bol. No 2, de la Est. Agrícola Central. México. Imp. Sria. Fomento.

29. Garcia-Merino, M. 1878. Las epidemias de las plantas en la Costa del Perú. Tipografía de la Sociedad de San Francisco. No 62. LimaPerú.

30. Garcia Rada, G. 1939. El "hielo" o "rancha" de la papa. En curso de Fitopatología Aplicada. Editado por Mimeographic Co. Lima. pp. $50-52$.

31. Goodwin, S. B., Cohen, B. A., and Fry, W. E. 1994. Panglobal distribution of a single clonal lineage of the Irish potato famine fungus. Proc. Natl. Acad. Sci. 91:11591-11595.

32. Herrera, F. L. 1919. Contribución a la flora del departamento del Cuzco. Rev. Universitaria (Cuzco-Perú) 8:2-98.

33. Hooker, W. 1980. Compendium of Potato Diseases. American Phytopathological Society, St. Paul, MN.

34. Jensen, J. L. 1887. Moyens de combatire et de détruire le Peronospora de la pomme de terre. Mem. Soc. Natl. Agric. France 131:31-156.

35. Johnston, F. R. S., and Fleming, J. F. 1845. Potato disease in Scotland, being results on the investigations into its nature and origin. William Blackwood and Sons, Edinburg.

36. Jones, J. B., Jones, J. P., Stall, R. E., and Zitter, T. A. 1991. Compendium of Tomato Diseases. American Phytopathological Society, St. Paul, MN.

37. Jones, L. R., Giddings, N. J., and Lutman, F. 1912. Investigations of the potato fungus Phytophthora infestans. U.S. Dep. Agric. Bur. Plant Ind. Bull. 245.

38. Lagerheim, G. de. 1890. La enfermedad de los pepinos. Su causa y su curación. Rev. Ecuat. 2:1-6.

39. Large, E. C. 1940. The Advance of the Fungi. Henry Holt \& Co., New York.

40. Marchal, M. le Ch. 1845. Extrait d'une notice sur la maladie des pommes de terre. Bull. Acad. Roy. Soc. Belles-Lettress Bruxelles. 12:376-381

41. Martens, M. 1845. Sur la maladie des pomme de terre. Bull. Acad. Roy. Soc. Belles-Lettres Bruxelles, 12(pt 2):356-375.

42. Minsheu, J. 1617. Ductor in Linguas (Guide into the tongues) and Vocabularium Hispaniculatinum (A most copious Spanish Dictionary). A facsimile reproduction with an introduction by Jurgen Shafer. Scholars' Facsimiles and Reprints. 1978. Delmar, New York.

43. Morren, Ch. 1845. Nouvelles instructions populaires sur les moyens de combattre et de détruire la maladie actuelle (Gragréne hu- mide) des pommes de terre. A la Librairie Encyclopédique de Roret. Paris.

44. Morren, Ch. 1846. The Potato Disease. An authentic and valuable memoir on the potato disease. Translated from the German, and sent by the translator to be published in the United States. John Skinner, ed. New York. Vol 1, pp. 386-389

45. Münter, J. 1846. Die Krankheiten der Kartoffeln, insbesondere die im Jahre 1845 pandemish herrschende nasse Fäule. Verlag von August Hirschwald, Berlin.

46. Niederhauser, J. S. 1954. Observations on late blight and other potato diseases in Peru. Plant Dis. Rep. 38:81-82.

47. Niederhauser, J. S. 1991. Phytophthora infestans: The Mexican connection. Pages 2545 in: Phytophthora. J. A. Lucas, R. C. Shattock, D. S. Shaw, and L. R. Cooke, eds. Br. Mycol. Soc. by Cambridge University, Cambridge.

48. Ochoa, C. M. 1991. The Andes, cradle of the potato. Diversity 7:45-47

49. Oyarzun, P. J., Ordoñez, M. E., Forbes, G. A., and Fry, W. E. 1997. First report of Phytophthora infestans A2 mating type in Ecuador. Plant Dis. 81:311.

50. Pachano, A. 1918. Dos enfermedades de las papas (Phytophthora infestans, Alternaria solani). Quinta Normal (Ambato, Ecuador) Est. Exp. Circ. 7:11.

51. Pachano, A. 1920. A fruit spot of cucumber (Phytophthora infestans). Boletín Agricultura. Quinta Normal (Ambato-Ecuador) 1:201-206.

52. Payen, M. 1846. Nouveau mode de propagation de l'altération spéciale des pommes de terre. C. R. Hebd. Séances Acad. Sci. (T. 23) 55:425-428.

53. Peterson, P. D., Jr., Campbell, C. L., and Griffith, C. S. 1992. James E. Teschemacher and the cause and management of potato blight in the United States. Plant Dis. 76:754756.

54. Plata, G., and Fernandez-Northcote, E. 1996. Determinación del tipo sexual de apareamiento en poblaciones de Phytophthora infestans que infectan a la papa en Bolivia. Compendio de Exposiciones de la IV Reunión Nacional de la Papa, Cochabamba-Bolivia. IBTA, PROINPA, UPS/SEPA, PROSEMPA. pp. 59-61.

55. Prunet, A. 1902. Le mildiou de la pomme de terre. Historique. Rev. Vitic. 17:663-666.

56. Real Academia Española, La. 1803. Diccionario de la Lengua Castellana. Madrid. Impreso en la casa de la Real Academia.

57. Reddick, D. 1928. Blight-resistant potatoes. Phytopathology 18:483-502.

58. Reddick, D. 1932. Some diseases of wild potatoes in Mexico. Phytopathology 22:609612.

59. Reddick, D. 1939. Whence came Phy- tophthora infestans? Chron. Bot. 5:410-412.

60. Rivera Peña, A. 1988. Interactions between wild tuber-bearing Solanum species and Phytophthora infestans (Mont.) de Bary in a natural habitat and implication of the results for potato breeding. Ph.D. thesis. Swedish University of Agricultural Sciences, Uppsala.

61. Robertson, N. F. 1991. The challenge of Phytophthora infestans. Pages 1-30 in: Advances in Plant Pathology. Phytophthora infestans, the Cause of Late Blight of Potato. D. S. Ingram and P. H. Williams, ed. Academic Press, Harcourt Brace Jovanovich, New York.

62. Roze, E. 1898. History de la pomme de terre, Paris. J. Rothchild, ed. Rue des Saints-Péres, Paris

63. Semal, J., Joly, P., and Lamy, D. 1983 L'épidémie de "Maladie del Pommes de Terre" causée en Europe in 1845 par le Phytophthora infestans (Mont.) de Bary: Les faits et les auteurs. Ann. Gembloux 89:79-99.

64. Sobrino, F. 1721. Diccionario nuevo de las Lenguas Española y Francesa. En Bruselas. En cafe de Francisco Foppens. Mercader de Libros.

65. Toro, R. A. 1927. Enfermedades y plagas de las plantas. Esc. Agric. Vet. Medellín Circ. No. 4.

66. Towsend, C. H. T., and Abbott, E. V. 1927 Enfermedades y pestes observadas en los cultivos de la Montaña central, Departamento de Junín, Huánuco. Est. Exp. Agric. La Molina. Soc. Nac. Agraria (Lima-Perú). Informe 1:1-14.

67. Turkensteen, L. J. 1978. Phytophthora in festans: Three new hosts and specialized form causing foliar blight of Solanum muricatum in Peru. Plant Dis. Rep. 62:829.

68. Ugent, D. 1968. The potato in Mexico: Geography and primitive culture. Econ. Bot 22:109-123.

69. Ugent, D. 1970. The potato. What is the botanical origin of this important crop plant, and how did it first become domesticated? Science 170:1161-1165.

70. Ugent, D., and Peterson, L. W. 1988. Archaeological remains of potato and sweet potato in Perú. Int. Potato Cent. Circ. 16:1-10.

71. UTEHA. 1984. Diccionario Enciclopédico. Talleres de "La Carpeta". S. A. México Tomo I (A-Azz).

72. Vanderghem, J. 1907. El Fitoftora infestans o enfermedad de la papa. Imprenta del Estado. Escuela de Artes y Oficios, Lima-Perú.

73. Vowinckle, O. 1926. Die Anfäligkeitdeutscher Kartoffelsorten gegenüber Phytophthora infestans (Mont.) de By., unter besonderer Berücksichtigung der Untersuchungsmethoden. Arb. Biol. Reichsanst. Land. Forstwirtsch. 14:588-641.

74. Zentmyer, G. A. 1988. Origin and distribution of four species of Phytophthora. Trans. Br. Mycol. Soc. 91:367-378. 